REGULAR ARTICLE

\title{
UNDERSTANDING THE MULTIPLE SOURCES DRIVERS OF AGRICULTURAL INCOME AMONGST SMALLHOLDER FARMERS IN SOUTHERN MALI
}

\author{
Bandiougou DEMBELE ${ }^{* 1,2}$, Hillary K. BETT ${ }^{1}$, Isaac Maina KARIUKI ${ }^{1}$, Marjorie Le BARS ${ }^{3}$
}

\author{
Address: \\ ${ }^{1}$ Department of Agricultural Economics and Agribusiness Management, Faculty of Agriculture, Egerton University, \\ Box 536-20115, Egerton Njoro, Kenya \\ ${ }^{2}$ Ins titut Economie Rurale (IER), Sikasso, Mali, Bp: 16 \\ ${ }^{3}$ Institut de recherche pour le développement (IRD), UMR GRED, 34394 Montpellier cedex 5 - France. \\ * Corresponding author: bandiougoud@gmail.com
}

\begin{abstract}
Multiple sources of income are important strategies for reducing smallholder farmer liquidity constraints and over dependency on single income source. However, farmers in Southern Mali, especially Malian high agricultural potential region are still faced with liquidity constraints resulting from low income from cash crop (cotton) production. Therefore, this study was carried out to understand the factors that motivate farmers' decision to engage in several incomegenerating activities. Cross-sectional data were collected from 134 randomly sampled smallholder farmers from three villages in different agro-ecological zones in Southern Mali. Multivariate probit (MVP) regression model was used to estimate the effect of socioeconomic and institutional factors on farmer participation in different sources of farm income. Correlation analysis showed that there is a significant correlation between the different income sources. Results from the econometric model revealed that the age of the family head determines the probability of farmers' participating in multiple sources of incomes, family size, dependency ratio, land tenure, education level, access to agricultural credit and extension services, cash crop income, off-farm income, input prices, agricultural output prices, and rural infrastructure. These results imply that policymakers and agricultural development programs should target strengthening of institutions as well as enhancement of farmers' access to productive resources.
\end{abstract}

Keywords: Drivers, Multiple sources, Income, Multivariate probit (MVP), Southern Mali JEL Codes : C01, C13, C31, Q12

\section{INTRODUCTION}

Agriculture is predominantly practiced by smallholder farmers in Sub-Saharan Africa (SSA) mainly for subsistence purposes. However, income generated from the main cash crops is still inadequate to improve household well-being. Specifically, cash crop income is insufficient in maintaining the economic and social welfare of smallholder farmers. For instance, income derived from the agricultural sector in developing countries fluctuates averagely between $55.8 \%$ and $64.1 \%$ (Eneyew \& Bekele, 2012; Birthal et al., 2014). Hence, smallholder farmers in SSA engage in multiple farm enterprises as a strategy for building resilience against poverty and food insecurity (World Bank, 2008; Ali \& Erenstein, 2017). Engaging in multiple sources of farm income is considered as a route to sustainable agricultural income and improved well-being. Smallholder farmer engagement in a number of farm income generating activities is seen as an opportunity for alleviating extreme food insecurity and poverty (Lay et al., 2008; Combary, 2015; Aababbo \& Sawore, 2016). For instance, Janvry \& Sadoulet (2001) and Fabusoro et al. (2010) showed that income from different farm enterprises is key to reducing smallholder farm income variability as well as a means of maximizing farm income. Besides, empirical studies have shown that specializing in one farm enterprise is rare in SSA (Winters et al., 2009; Davis et al., 2017).

Therefore, engaging in multiple sources of farm income remains a common form of income diversification strategies in rural areas. In SSA, smallholder farmers engage in multiple farm income generating activities to improve their living conditions as well as a way of spreading risks (Birthal et al., 2014; Mentamo \& Regassa, 2016). Scholars emphasize that access to market, quantity, and quality of agricultural products, geographical location among other factors play a central role in determining the structure of the rural economy and farmer participation in multiple agricultural activities (van Schalkwyk et al., 2012; Arinloye et al., 2015; Tarekegn et al., 2017). However, smallholder farmer's participation in the agricultural market outlet can be affected by farmer's characteristic, institutional factors, and market dynamics. Van Schalkwyk et al. (2012) found out that farmers' participation in agricultural marketing outlet depends on factors such as infrastructure, prices incentive, transportation cost among others.

Cotton constitutes the main source of income for smallholder farmers in Southern Mali. The area under cotton production is almost 50 percent of the total arable land area, indicating the importance of cotton in the country. Although Southern Mali is the main agricultural 
production zone in Mali, income generated from cash crop remains low and is subjected to frequent fluctuations (Theriault et al., 2013; Traore et al., 2015). Specifically, income generated from cotton production is inadequate to cover smallholder farmers' daily expenditure. Hence, smallholder farmers in Southern Mali engage in the selling of output from other farm enterprises to supplement the little income from cotton production. Therefore, in addition to cotton production, farmers in the region also participate in food crop production, livestock rearing, vegetable and horticultural production. The sale of surplus food crops, vegetable, horticultural produce, and cattle, supplement income generated from cotton production.

Moreover, understanding of the factors influencing farmers' decision to engage in the production and marketing of crop produce and cattle remains the starting point for diversifying smallholder farmer sources of income and improving rural livelihoods. Several studies have applied a number of econometric models in estimating the effect of socio-economic and institutional factors on smallholder farmer decision to engage in the production and marketing of crop and livestock. The commonly used models include ordinary least squares regression, conditional fixed effects logit, multinomial logistic and tobit model among others (Abdulai \& Crolerees, 2001; Combary, 2015; Loison \& Bignebat, 2017). In this paper, a multivariate probit regression (MVP) model was used to estimate the effect of socioeconomic and institutional factors on smallholder farmer participation in multiple sources of farm income.

\section{METHODOLOGY OF RESEARCH}

\section{Study area}

The study was conducted in three selected villages of three districts located in different agro-ecological zones in cotton growing area. In Beguene (old basin) Bla district of the northern part of Southern Mali, the main agricultural enterprises are cotton, maize, sorghum, millet and livestock rearing (cattle, sheep, and goat). The area receives an average annual rainfall of around $850 \mathrm{~mm}$, with a high inter-annual variability. The second village is Ziguena (intermediate or center), which is located in Sikasso district. On average, it receives an annual rainfall of about $1000 \mathrm{~mm}$. Cotton, maize, sorghum, millet and livestock rearing are the dominant agricultural activities. The last village is Nafegue which is located in Kadiolo district in Southern part of the cotton-growing zone. Nafegue receives an average rainfall of more than $1200 \mathrm{~mm}$ per year. Agricultural activities in Nafegue include cotton, maize, millet, sorghum and livestock production. Besides the main agricultural enterprises, there is also rice, groundnut, cowpea production, vegetable production, horticulture among others in the cotton zone of Mali. Agriculture is the main occupation for the smallholder farmers in the cotton growing zone in Mali. Interestingly, there is no rental land for cultivation in the cotton growing zone of Mali. Smallholder farmers also engage in other activities such as informal trade, traditional gold mining and the sale of firewood among others.

\section{Sample size and data collection}

The study used a multistage sampling technique which involved a combination of purposive, stratified and simple random sampling procedures. The first stage involved purposive selection of three districts in the cotton growing area. In the second stage, one commune from each district was randomly selected, thus obtaining three communes. In the third stage, three villages were selected, and a sample of 134 smallholder farmers was obtained. The research unit was the farming family. A cross-sectional survey was conducted to obtained data from 134 smallholder farmers were randomly selected. A semi-structured questionnaire was designed and administered to the smallholder farmers to obtain data on socioeconomic factors, nonfarm activities such as the sale of firewood, informal trade, migration, gold mining.

\section{Conceptual framework and econometric estimation}

Multiple income generation strategies are forms of protection measures that help in reducing poverty levels, food insecurity, and the risks of climatic conditions. Following Teklewold et al. (2013); Arinloye et al. (2015) and Tarekegn et al. (2017), smallholder farmer's choice for multiple sources of agriculture income can be conceptualized using a random utility model (RUM). The RUM is particularly appropriate for modelling discrete choice decisions. It offers an indirect utility function where an individual farmer with specific characteristics associates average utility level to each alternative strategy in a choice set. Thus, it provided a certain level of utility $U_{i j}$ from each alternative. The model is based on the principle that smallholder farmers choose to maximize their utility. Therefore, the utility was decomposed into two components observed exogenous variables $\left(X_{i j}\right)$ and stochastic normally distributed $\left(\varepsilon_{i j}\right)$ terms:

$U_{i j=} X_{i j} \beta_{j}+\varepsilon_{i j}$

Where $X_{i}$ is observed exogenous variables including all factors that influence the utility and $\varepsilon_{i j}$ is unobserved characteristics.

Consider the $i^{\text {th }}$ smallholder farm $(\mathrm{i}=1, \ldots, \mathrm{N})$ facing farmer's decision on whether or not to participate in multiple sources of agricultural income. Let $U_{0}$ represent the benefit of unique source of farm income and $U_{j}$ represent the benefit to the farmer for choosing the $J^{t h}$ multiple sources of agricultural income $j=1 ; 2 ; 3$ and 4; where $j$ denotes the choice of food crop sale (fc), participation in vegetable production sale (vp), horticultural production sale (hp), and sale of cattle (c). The farmer decides to choose the $J^{\text {th }}$ multiple sources of agricultural income if the utility $Y_{i j}^{*}=U_{j}^{*}-U_{0}>0$. The net benefit $\left(Y_{i j}^{*}\right)$ that farmer derives from the multiple sources of agricultural income $J^{t h}$ is a latent variable determined by observed exogenous variables $\left(X_{i j}\right)$ and stochastic error term $\left(\varepsilon_{i j}\right)$ :

$Y_{i j}^{*}=X^{\prime}{ }_{i j} \beta_{j}+\varepsilon_{i j} \quad(\mathrm{~J}=\mathrm{fc}, \mathrm{vp}, \mathrm{hp}, \mathrm{c})$.

Hence, using the indicator function, the unobserved 
preferences in Eq (1) translate into the observed binary outcome equation for each choice as follows:

$$
Y_{i j}^{*}=\left\{\begin{array}{l}
1 \text { if } Y_{i j}^{*}>0 \\
0 \text { Otherwise }
\end{array} \quad(\mathrm{J}=\mathrm{fc}, \mathrm{vp}, \mathrm{hp}, \mathrm{c})\right.
$$

In multivariate probit model, where the options of several strategies of income diversification are possible, the error terms follow a multivariate normal distribution (MVN) with zero conditional mean and variance normalized to unity (for identification of parameters), where $u_{f c}, u_{p v}, u_{p h}, u_{c} \sim \operatorname{MNV}(0, \Omega)$ and the symmetric covariance matrix is given by:

$$
\Omega=\left(\begin{array}{cccc}
1 & \rho f c v p & \rho f c h p & \rho f c c \\
\rho v p f c & 1 & \rho v p h p & \rho v p c \\
\rho h p f c & \rho h p v p & 1 & \rho h p c \\
\rho c f c & \rho c v p & \rho c h p & 1
\end{array}\right)
$$

Where $\rho$ denotes the pairwise correlation coefficient for the error terms corresponding to any two equations to be estimated in the model. The off-diagonal elements in the covariance matrix represents the unobserved characteristic that affects the choice of alternative options. The regression coefficients of the MVP can be interpreted using the marginal effects of change in the explanatory variable on the expected value of the dependent variable (Greene, 2002; Wooldridge, 2002). A positive correlation between variables is interpreted as a complementary relationship, whereas a negative correlation between variables is interpreted as being a substitute.

Table 1 provides the expected sign of explanatory variables used in the models. Age is hypothesized to have either a positive or negative effect on the decision to the sale and the income generated from the four strategies. Land ownership is expected to have a positive influence on multiple sources of income and the amount of income that each source generates. In rural areas, a large family size implies availability of labour and, therefore, it is hypothesized to have a positive effect on the diversity of agricultural activities as well as economic proceeds from the activities. The dependency ratio is expected to have a positive influence on the number of farm enterprises and either a positive or negative influence on income generated from multiple farm enterprises. Education level is an important capital for enhancing the diversity of the source of income. The study expects education to positively influence the sale of produce from the four enterprises and the amount of income received by farmers.

Institutional factors such as access to agricultural credit and extension services are hypothesized to influence smallholder farmer income generation activities positively. Income from cash crop (cotton) is expected to influence the diversity of other farm income generating activities positively. Off-farm income is expected to have both negative and positive influence on income generated from the four farm enterprises. Income from off-farm activities can be invested in agriculture, contributing to diverse sources of farm income. Off-farm income, on the other hand, may also discourage the sale of farm produce by influencing farmers to produce for self-consumption and not for the market. Agricultural input prices and output price are hypothesized to negatively influence smallholder farmer income, and state of rural infrastructure are expected to either have a positive or negative association with the sale of farm produce and income generated from the sale.

\begin{tabular}{|c|c|c|c|}
\hline Variable & Description & & Expected sign \\
\hline \multicolumn{4}{|l|}{ Dependent variable } \\
\hline \multirow{4}{*}{$\begin{array}{l}\text { Multiple sources of income } \\
\text { generation strategies }\end{array}$} & Food crop sale & & \\
\hline & Vegetable production sale & & \\
\hline & Horticulture production sale & & \\
\hline & Cattle sale & & \\
\hline \multicolumn{4}{|l|}{ Explanatory variable } \\
\hline Land ow nership & Land ow nership & Dummy, yes $=1 ; \mathrm{No}=0$ & + \\
\hline Education & Education level & Dummy, yes $=1 ; \mathrm{No}=0$ & + \\
\hline Credit & Access to credit & Dummy, yes $=1 ; \mathrm{No}=0$ & + \\
\hline Extension & Access to agricultural extension services & Dummy, yes $=1 ; \mathrm{No}=0$ & + \\
\hline HpriceAinput & High price of agricultural inputs & Dummy, yes $=1 ; \mathrm{No}=0$ & - \\
\hline Infrastructure & Poor infrastructure & Dummy, yes $=1 ; \mathrm{No}=0$ & $-/+$ \\
\hline LPagri products & Low price of agricultural products & Dummy, yes $=1 ; \mathrm{No}=0$ & - \\
\hline Age & Age of family head & Continuous & $+/-$ \\
\hline Family size & Family size & Continuous & + \\
\hline Dependrotio & Dependency ratio & Continuous & $+/-$ \\
\hline Cash crop & Cotton income in FCFA & Continuous & + \\
\hline Off farm & Total off income in FCFA & Continuous & $-/+$ \\
\hline
\end{tabular}

Table 1: Description, measurements and expected sign of variables 


\section{RESULTS AND DISCUSSIONS}

\section{Descriptive statistics of dependent and independent variables}

Table 2 provides descriptive statistics of variables used in the model. Food crop sale is the sale of surplus maize, millet, and sorghum. The sale of food crops enables smallholder farmers to supplement the incomes from cotton production to meet the daily family expenditure. Despite the role played by food crops in food security in Southern Mali and Mali in general, the sale of food crops is widely practiced in the cotton growing zone. About 77\% of the sampled smallholder farmers sold food crops. The sale of food crops may result in food shortages before the end of the growing season which is mainly from August to September. In addition, a majority of smallholder farmers sells and later buys staple food at high prices before the new harvest.

The sale of vegetable produce (tomatoes, potatoes, cucumber, among others) was also considered as an important alternative income-generating activity by smallholder farmers. About $32 \%$ of the sampled smallholder farmers engaged in vegetable production and marketing. However, vegetable production is limited by lack of water. It is essential to indicate that vegetables are mainly grown during the dry season when water availability is a significant problem. This constitutes a major obstacle to farmers' participation in the vegetable output market.

Horticulture is another source of income. About $40 \%$ of the surveyed farmers sold horticultural produce. Horticultural crops commonly grown for sale in the study area include mangoes, oranges, cashew nuts, and bananas. The produce is mainly consumed at home largely due to lack of market. Most of the horticultural producers sold their produce within the village at low prices. Therefore, the sale of horticultural produce is undertaken by smallholder farmers in the study area as a secondary income generating activity and as a strategy for income diversification.

Livestock sale is defined as the sale of cattle. Historically, herd size cattle are from cotton investment and common pool resources. The decision to sell cattle in Southern Mali usually involve at least three family members, depending on the size of the family. About $32 \%$ of sampled farmers sold cattle annually. The sale of cattle is usually made when a family is faced with enormous social events (dowry, burial ceremony, wedding, and health), financial constraints such as the acquisition of tractor or reimbursement of agricul tural credit.

Family farming heterogeneity includes the age of the family head (chief of the family), education level, family size and land tenure. These are relevant variables that may influence smallholder farmers' decision to engage in several income generation strategies. In the study area, all families are male-headed. The descriptive statistics in Table 2 show that on average, the mean age family head is around 56 years old. The families headed by an older farmer, have more experience in agricultural practices and possesses an indigenous knowledge, thus likely to undertake multiple sources income activities to improve their livelihood. Education level, also, has a positive effect on income strategies. About $51 \%$ did not attend formal school, and $49 \%$ of the family head had attended formal school up to primary level.

The well-being of families in the cotton growing zone in Mali is determined by the family size and ow nership of land, cattle and agricultural equipment. On average, a smallholder farming family had 23 people living under the same roof and sharing common family resources. About $85 \%$ of smallholder farmers in the study area own land. Landlessness in Southern Mali is associated with immigration. However, the landless had access to land. The dependency ratio is the proportion of farming family members aged below 15 years and above 64 years to the number of farming family members aged between 15 and 64 years. The average dependency ratio for the sampled farming families was 1 . On average, farmers had 1201 FCFA as total annual income from cash crop. The results also indicate that non-farm activities are important sources of income among farmers. On average, farmers earned 346,276 FCFA from non-farm income-generating activities.

For turning to the institutional variables, about $19 \%$ of farmers had access to credit to invest in small businesses and informal grain trade. Agricultural extension services are important avenues for improving farmers' engagement in agriculture. Extension agents provide advisory services, share knowledge and provide information about the agricul tural production. About 18\% of smallholder farmers had access to extension services. About $77 \%$ of smallholder farmers indicated that input prices were high, thereby discouraging them from engaging in multiple agricultural enterprises. The survey result revealed that a majority, about $81 \%$, of the sampled smallholder farmers realized low agricultural output prices. Lastly, infrastructure refers to the state of rural roads that link villages to the main markets. Results also showed that about $40 \%$ of farmers faced challenges in accessing markets primarily due to the poor roads. Poor roads may cause severe damage to perishable products as a result of delayed delivery to the market.

\section{Econometric results (MVP) of multiple sources of income}

The result in Table 3 shows that there are differences in income-generating strategies among smallholder farmers. This is demonstrated by the likelihood test ratio of the estimated correlation matrix. The $\rho$ values show the degree of correlation between each pairwise of dependent variables. The $\rho_{3}$ is the correlation between cattle sale and vegetable sale and the $\rho_{4}$ correlation between food crop sale, vegetable sale, and horticulture sale. The $\rho_{3}$ and $\rho_{4}$ are both positively and negatively interdependent, and significant at $1 \%$ and $5 \%$ levels of probability, respectively. This finding indicates that farmers who generate income from cattle sale $\rho_{3}$ are less likely to generate income from the vegetable sale $\rho_{2}$. Similarly, farmers who have undertaken horticulture are more likely to multiply their income from food crop sale $\rho_{1}$ and less likely to participate in vegetable sale $\rho_{2}$. The simulated maximum likelihood (SML) estimation indicates that the probability of income generation strategies that farmers 
undertook such as cattle sale, horticulture, and food crop sale were 30,46 and $82 \%$ respectively. The probability of farmers selling food crop is quite high (82\%) as compared to cattle sellers and horticulture sellers. The joint probabilities of success or failure of multiple sources of income show that farmers are less or more likely to multiply their income from different agricultural sources. The likelihood of farmers to diversify into several incomes source or not are around $6 \%$ and $9 \%$ for success and failure, respectively.

Based on the result of likelihood ratio test in the model (LR $\left.\chi^{2}(6)=19.438, p=0.004\right)$, which indicates the null hypothesis that the interdependence between income generation strategies (hypothesis of zero correlation) of the error terms was rejected. This result is also supported by the significant coefficients of the pairwise correlation of error terms (Table 3). The significant value of the Wald test $\left.\chi^{2}(48)=139.12, p=0.000\right)$ ) is significant at $1 \%$ level of probability and allows us to reject the conjoint nullity of variable coefficients included in the estimation. Thus, the MVP model fits the data reasonably well. These results also show the complementary (positive) relationship and or negative correlation amongst diverse sources of income generation strategies decision.

Table 2: Descriptive statistics of the variables used in the analysis

\begin{tabular}{|c|c|c|c|c|}
\hline Variables & Description & \multicolumn{2}{|c|}{ Frequency } & Percentage \\
\hline \multicolumn{5}{|c|}{ Dependent variables for Multiple sources of income (Dummy: Yes $=1 ;$ No $=0$ ) } \\
\hline \multirow[t]{2}{*}{$\mathrm{Fc}$} & Food crop & Yes & 103 & 76.87 \\
\hline & & No & 31 & 23.13 \\
\hline \multirow[t]{2}{*}{$\mathrm{Vp}$} & Vegetable production & Yes & 43 & 32.09 \\
\hline & & No & 91 & 67.91 \\
\hline \multirow[t]{2}{*}{ Hp } & Horticulture production & Yes & 54 & 40.3 \\
\hline & & No & 80 & 59.7 \\
\hline \multirow[t]{2}{*}{ Cs } & Cattle sale & Yes & 43 & 32.09 \\
\hline & & No & 91 & 67.91 \\
\hline \multicolumn{5}{|c|}{ Independent dummy variables } \\
\hline \multirow[t]{2}{*}{ Land ow nership } & & Yes & 114 & 85 \\
\hline & & No & 20 & 15 \\
\hline \multirow{2}{*}{ Education form } & & Yes & 66 & 49.25 \\
\hline & & No & 68 & 50.75 \\
\hline \multirow[t]{2}{*}{ Credit } & access to credit & Yes & 26 & 19.4 \\
\hline & & No & 108 & 80.6 \\
\hline \multirow[t]{2}{*}{ Extension } & extension services & Yes & 18 & 13.43 \\
\hline & & No & 116 & 86.57 \\
\hline \multirow[t]{2}{*}{ Hcostagri inputs } & High cost agricultural inputs & Yes & 103 & 76.87 \\
\hline & & No & 31 & 23.13 \\
\hline \multirow[t]{2}{*}{ Infrastructure } & Poor infrastructure & Yes & 53 & 39.55 \\
\hline & & No & 81 & 60.45 \\
\hline \multirow[t]{2}{*}{ L P agri products } & Low price Agri products & Yes & 108 & 80.6 \\
\hline & & No & 26 & 19.4 \\
\hline \multicolumn{3}{|c|}{ Independent continuous variables } & Mean & SD \\
\hline Age & Age of family head & & 56 & 15 \\
\hline Family size & Number of people & & 23 & 19.11 \\
\hline In cash crop & Cotton income in FCFA & & 1201 & 1750 \\
\hline ln off farm income & Total off income in FCFA & & 346276 & 590735 \\
\hline Dependency ratio & Dependency ratio & & 1 & 0.21 \\
\hline
\end{tabular}

Note: The exchange rate at the time of the survey was 558 FCFA (Franc of the African Financial Community) for USD.

Table 3: Correlation matrix of different sources of income from Multivariate probit (MVP)

\begin{tabular}{lllll}
\hline Variables & Food crop sale & Vegetable sale & Cattle sale & Horticulture \\
\hline$\rho_{1}$ & 1 & 2 & 3 & 4 \\
$\rho_{2}$ & $-0.180(0.237)$ & & \\
$\rho_{3}$ & $0.138(0.271)$ & $-0.502(0.031)^{* *}$ & & \\
$\rho_{4}$ & $0.360(0.010) * * *$ & $-0.340(0.021)^{* *}$ & $-0.064(0.698)$ & 1 \\
Predicted probability & 0.82 & -1.02 & -0.70 & -0.54 \\
Joint probability (success) & 0.06 & & & \\
Joint probability(failure) & 0.09 & & & \\
\hline Note: $* * *, * *$, significant at 1 and $5 \%$ levels respectively and the figures in the parenthesis are standard errors
\end{tabular}


Table 4 provides results from the MVP model. The results indicate that some of the variables were significant at more than one source of income whereas other variables were significant in only one source income generation strategy. For food crop sale any of the explanatory variables were not significant. All explanatory variables included in the model were significant and affected one of the dependent variables. Therefore, out of twelve independent variables, eight were significant at the vegetable sale, four variables affected cattle sale, and three variables affected horticulture sale in the study area at different probability levels.

The coefficient of the age of the family head had a positive and significant relationship with the sale of cattle at a 5\% significance level. Older farmers are more likely to be more experienced in the management of family resources than younger farmers. Age increases the capacity of farmers to manage and control livestock income. It also increases individual autonomy in rural family setups. Hence, older farmers in the study area tend to have a greater influence on cattle marketing decisions. This finding is inconsistent with results reported by Tuyen (2015) who indicated that income decreases with the age of farmers in mountainous regions in Vietnam. Also, older persons are more informed and knowledgeable of important needs, thereby likely to identify cattle as a source of income to finance their family expenditure. This finding is in line with the study conducted by Marandure et al. (2016) who found out that old farmers seek to emphasize the social role of cattle and are more risk averse than their younger counterparts.

Family size was positively and significantly associated with the sale of cattle at a 5\% significance level. Families with more members are more likely to sell cattle. This indicates that family size in rural areas determines the probability of selling cattle in the cotton growing zone of Mali. Families with many members were more likely to sell cattle to meet their needs. The sale of cattle is possibly intended to support large per capita expenditure. For instance, large families have large auto-consumption expenses on health, food, dowry, and education. Therefore, income from cash crop is insufficient in covering the family expenditure, hence, compelling farmers to sell cattle. This finding is in agreement with Morris et al. (2017) who reported that income diversification strategies play an important role of the family structure and social context.

Land ownership had a positive and statistically significant influence on the sale of vegetable and cattle at a $10 \%$ significance level. The direction of the relationship between the sale of vegetable and cattle and landholding is not surprising because land is an important productive resource which influences agricultural productivity. Farmers who own larger land sizes possibly produced more vegetable and cattle which influenced the decision to sale. Land ownership motivates farmers to allocate more land to vegetable and cattle production which, in turn, results in increased productivity. Increased productivity of vegetable is an important push factor that motivates farming families to participate in the output market. Fosu-Mensah et al. (2012) and Kassie et al.
(2017) who reported that land tenure is the most important factor of production in rural areas to diversify agricultural income activities.

Dependency ratio was positively and significantly associated with the sale of vegetable at a $10 \%$ significance level. Smallholder farmers with a high number of dependants were more likely to participate in vegetable production and selling. High dependency ratio suggests that the economically active family members are burdened by high family expenditure, resulting in depressed per capita consumption. Consequently, families may resort to selling vegetables as they seek to improve per capita consumption. The sale is also possibly made to ease the economic burden on the economically active members. This finding is inconsistent with Randela et al. (2008) who reported that the dependency ratio reduced the level of farmer participation in the output market in the family.

Access to credit by smallholder farmers was positively associated with the sale of vegetable at $1 \%$ significance level. The regression coefficient suggests that farmers who had access to farm credit were likely to sell vegetables. In other words, access to credit facilitated agricultural production and marketing of vegetables. Credit improves the economic power of farmers, enabling them to acquire critical inputs for increased vegetable production. This indicates that credit ensures higher market participation by farmers since it incentivizes farmers to produce vegetables beyond consumption to enable them to offset the cost of credit and gain additional income. Farmers who had access to credit were possibly able to produce marketable vegetable surpluses. This is consistent with (Maertens et al., 2012; Abu et al., 2016).

Access to extension services negatively and significantly influenced the decision to sell vegetable at $1 \%$ level of probability. This indicates that farmers were not adequately persuaded to sell vegetables by receiving extension information about vegetable production and marketing. Extension information negatively influenced farmers' perception of producing vegetables for the market. This is contrary to the priori expectation that extension services encourage farmer participation in the output market. The possible explanation for this unexpected outcome is that probably extension agents emphasized the achievement of dietary diversity and alleviating malnutrition when providing information about the vegetable production. This finding is inconsistent with Abate et al. (2015); Ahmed et al. (2017) and Tarekegn et al. (2017) who reported that extension contacts positively influence farmer participation in the output market.

Cash crop income was positively and significantly associated with the sale of vegetable at 5\% levels of probability. This is not surprising since farmers who generate more income from cash crop are more likely to invest in other farm enterprises. Additionally, cash crop farmers may allocate labour to vegetable production during the dry season. In turn, farmers sell vegetables to smooth consumption against income shock that may result from the unavailability of cash crop income. In this context, multiplication of income sources is important in complementing the primary source of income. Farmers 
may also seek to produce and market vegetables as a result of fluctuations of cotton output and prices and climatic conditions.

Off-farm income negatively and significantly influenced the sale of vegetable. This implies that farmer who participated in non-farm activities were less likely to sell vegetables. Off-farm income directly supports the survival of the farming family. Therefore, farmers are less motivated to engage in sale of vegetables. In addition, farmers in the study area engage in small business, informal trade, wage labour and traditional gold mining during the dry season. Therefore, income generated from these activities may adequately complement cash crop income, preventing farmers from selling vegetables. Additionally, off-farm income creates new sources of family income which is not related to main sources of livelihood in rural areas. This is in line with Rios $\boldsymbol{e t} \boldsymbol{a l}$. (2008) and Omiti \& Mccullough (2009) who argued that with higher income from off-farm discourage farmers from farming and lead to low market participation.

Education level had a positive and significant relationship with the sale of cattle at 5\% level of probability Farmers who are more educated are more likely to be informed about output markets. Higher education enables farmers to reduce transaction cost and to possess better bargaining power. Education affords farming families with better knowledge of cattle production and marketing. Hence, knowledge and information on existing market opportunities influence farmers to focus on market-oriented cattle production. This finding is in line with Seng (2016) and Emukule $\boldsymbol{e t}$ al. (2018) who argued that farmers with higher education level could modify production systems to opt for innovative technologies and market rules. In contrast to its effect on cattle sale, education negatively influenced the probability of farmers selling horticultural products. Horticultural commodities in Southern Mali results in low market prices. Hence, educated farmers have less focus on low return from horticultural crops. In addition, the level of education in the study area is low and, therefore, farmers are less likely to seek more information on horticultural production and marketing. This is consistent with Abdullah et al. (2017) who indicated that farmers with low education participate few income-generating activities.

The high cost of agricultural inputs had a positive and significant relationship with the sale of horticultural commodities at $5 \%$ level of probability. Since high input prices reduce a farmer access to important inputs for horticultural production. Low access to inputs results in low productivity which translates to low participation in the output markets. Output price had a negative and significant relationship with the sale of vegetable at $5 \%$ level of probability. This is expected since low agricultural output prices discourage farmers from participating in the production and marketing of agricultural commodities. Low output prices represent low returns on investment in agricultural production. Farmers are less incentivized to produce and sale when the output attracts low prices.

Infrastructure had a positive and significant relationship with the sale of vegetable at $1 \%$ level of probability. This implies that with the good infrastructural network (roads), farmers are more likely to participate in the marketing of vegetable products. Good infrastructural network tends to decrease the transaction costs, hence increasing the number of agricultural products supplied to the market. This finding corroborates the results by Abro (2012) and Sebatta et al. (2014) who indicated that poor road network increases transaction cost for delivering goods, thereby limiting farmer's participation in the market outlet. However, infrastructure was negatively and significantly associated with the sale of horticultural commodities at $5 \%$ level of probability. On the other hand, poor infrastructure reduces farmer's participation in the horticultural output market. Poor road network reduces the level of economic activities since it disconnects farmers from market opportunities. This finding is in agreement with previous studies conducted in the Great Lakes countries of Burundi, Rwanda, the Democratic Republic of Congo and in Bangladesh (Jagwe et al., 2010; Sultana et al., 2015).

Table 4: Multivariate probit (MVP) estimates for multiple sources of income

\begin{tabular}{|c|c|c|c|c|c|c|c|c|}
\hline & \multicolumn{2}{|c|}{ Food crop sale } & \multicolumn{2}{|c|}{ Vegetable sale } & \multicolumn{2}{|c|}{ Cattle sale } & \multicolumn{2}{|c|}{ Horticulture sale } \\
\hline & Coef. & $\mathrm{SE}$ & Coef. & $\mathrm{SE}$ & Coef. & $\mathrm{SE}$ & Coef. & SE \\
\hline Age HF & 0.006 & 0.009 & 0.001 & 0.011 & 0.020 & $0.010 * *$ & 0.006 & 0.008 \\
\hline Family size & -0.008 & 0.007 & 0.007 & 0.008 & 0.022 & $0.01 * *$ & 0.006 & 0.008 \\
\hline Dep. Ratio & -0.528 & 0.688 & 1.590 & $0.890^{*}$ & 0.173 & 0.847 & 0.756 & 0.777 \\
\hline Extension & -0.144 & 0.368 & -1.16 & $0.40 * * *$ & 0.118 & 0.350 & -0.45 & 0.369 \\
\hline Access credit & -0.186 & 0.316 & 1.029 & $0.35 * * *$ & 0.420 & 0.311 & 0.265 & 0.313 \\
\hline Ln cash crop & 0.028 & 0.027 & 0.103 & $0.044 * *$ & 0.040 & 0.035 & 0.031 & 0.010 \\
\hline Ln off farm & 0.014 & 0.027 & -0.098 & $0.029 * * *$ & 0.000 & 0.028 & 0.022 & 0.027 \\
\hline Education & 0.363 & 0.269 & -0.242 & 0.257 & 0.632 & $0.278 * *$ & -0.465 & $0.245^{*}$ \\
\hline hpriceagriinp & -0.411 & 0.373 & 0.461 & 0.406 & -0.340 & 0.304 & 0.727 & $0.336 * *$ \\
\hline Infrastructure & -0.171 & 0.263 & 0.920 & $0.261 * * *$ & 0.286 & 0.245 & -0.590 & $0.249 * *$ \\
\hline lpriceagri & 0.199 & 0.348 & -0.967 & $0.400 * *$ & -0.165 & 0.352 & -0.288 & 0.340 \\
\hline Land own & 0.411 & 0.328 & 0.585 & $0.347^{*}$ & 0.586 & $0.347 *$ & 0.413 & 0.379 \\
\hline Constant & 0.260 & 0.803 & -2.303 & 1.170 & -3.323 & $1.07 * * *$ & -2.022 & $0.86^{* *}$ \\
\hline
\end{tabular}

Note: *** and *** significance levels at $10 \%, 5 \%$ and $1 \%$ respectively. 


\section{CONCLUSIONS RECOMMENDATION}

AND

The study focused on four essential agricultural sources of income, including food crop surplus sale, vegetable sale, horticultural sale, and cattle sale. Multivariate probit regression was used to estimate the possible correlation between different dependent variables. However, the results show that about $77 \%$ of sampled farmers sold food crops surplus, $40 \%$ participated in horticulture production sale, and $32 \%$ of sampled farmers participated in the sale of vegetable production market and the sale of cattle. The results indicate that there are substantial complementarity and substitutability among sources of income. Correlation matrix analysis showed a positive and negative correlation which was not statistically significant among different sources of income generation. Econometric results show that age of family head, family size, dependency ratio, land ownership, education level, cash crop income, offfarm income, access to credit, high cost of agricultural inputs, infrastructure and price of agricultural commodities positively and significantly influenced the likelihood of farmer participation in vegetable and horticultural production and marketing. The results also indicate that extension services, education level, and infrastructure negatively influenced farming family participation in vegetable and horticulture production and marketing. The major recommendation is that, smallholder farmers in Southern-Mali should consider, vegetable and horticulture production for commercial purposes not for subsistence agriculture. Based on findings, subsidized agricultural inputs will enhance smallholder livelihood improvement through increased agricultural productivity and participation in the market outlet.

\section{Acknowledgment}

This material is based upon work supported by the United States Agency for International Development as part of the Feed the Future initiative under the CGIAR Fund award number BFS-G-11-00002 and the predecessor fund the Food Security and Crisis Mitigation II grant award number EEM-G-00-04-00013. Special thanks to the anonymous reviewers for their helpful comments and suggestions on the first version of the paper. The assistance of technicians in data collection and farmers in three villages is well appreciated.

\section{REFERENCES}

AABABBO, Y. E. \& SAWORE, A. M. (2016). Assessing determinant factors of income diversification among rural farm households in Ethiopia: The case of Leemo and Anileemo Districts, Hadiya zone, South nation nationalities people region. International Journal of Science and Research, 5(12), 100-110. http://doi.org/10.21275/ART20163308

ABATE, T., SHIFERAW, B., MENKIR, A., WEGARY, D., KEBEDE, Y., TESFAYE, K. \& KENO, T. (2015). Factors that transformed maize productivity in Ethiopia. Food Security, 7, 965-981. http://doi.org/10.1007/s12571-015-0488-z
ABDULAI, A. \& CROLEREES, A. (2001). Determinants of Income Diversification among Rural Households in Southern Mali Determinants of income diversification amongst rural households in Southern Mali. Food Policy, 26, 437-452. http://doi.org/10.1016/S03069192(01)00013-6

ABDULLAH, RABBI, F., AHAMAD, R., ALI, S., ALI, A., AHMAD, W. \& ILYAS, A. (2017). Determinants of commercialization and its impact on the welfare of smallholder rice farmers by using Heckman's two-stage approach. Journal of the Saudi Society of Agricultural Sciences, 10. http://doi.org/10.1016/j.jssas.2017.06.001

ABRO, A. A. (2012). Determinants of crop diversification towards high-value crops in Pakistan. International Journal of Business Management Economics Resources, 3(3), 536-545.

ABU, B. M., ISSAHAKU, H. \& NKEGBE, P. K. (2016). Farmgate versus market center sales: a multi-crop approach. Agricultural and Food Economics, 4, 1-17. http://doi.org/10.1186/s40100-016-0065-6

AHMED, M. H., GELETA, K. M., TAZEZE, A., MESFIN, H. M. \& TILAHUN, E. A. (2017). Cropping systems diversification, improved seed, manure and inorganic fertilizer adoption by maize producers of eastern Ethiopia. Journal of Economic Structures, 6, 1-16. http://doi.org/10.1186/s40008-017-0093-8

ALI, A. \& ERENSTEIN, O. (2017). Assessing farmer use of climate change adaptation practices and impacts on food security and poverty in Pakistan. Climate Risk Management, 16 ,

183-194.

http://doi.org/10.1016/j.crm.2016.12.001

ARINLOYE, D. A. A., PASCUCCI, S., ANITA, R., COULIBALY, O. N., HAGELAAR, G. \& ONNO, S. (2015). Marketing Channel Selection by Smallholder Farmers. Journal of Food Products Marketing, 21, 337357. http://doi.org/10.1080/10454446.2013.856052

BIRTHAL, P. S., NEGI, D. S., JHA, A. K. \& SINGH, D. (2014). Income Sources of Farm Households in India: Determinants, Distributional Consequences, and Policy Implications. Agricultural Economics Research Review, 27(1), 37-48. $\quad$ http://doi.org/10.5958/j.0974$\underline{0279.27 .1 .003}$

COMBARY, O. S. (2015). Determining factors of the strategies for diversifying sources of income for rural households in Burkina Faso. Journal of Development and Agricultural Economics, 7(1), 20-28. http://doi.org/10.5897/JDAE2014.0607

DAVIS, B., DI GIUSEPPE, S. \& ZEZZA, A. (2017). Are African households (not) leaving agriculture? Patterns of households' income sources in rural Sub-Saharan Africa. Food Policy, 67, 153-174. http://doi.org/10.1016/j.foodpol.2016.09.018

EMUKULE, J. I., KIPSAT, M. J. \& WAMBUI, C. C. (2018). Determinants of Households' Market Participation around Community Milk Cooling Plants, Western Kenya. Journal of Agricultural Science, 10(3), 204-212. http://doi.org/10.5539/jas.v10n3p204

ENEYEW, A. \& BEKELE, W. (2012). Determinants of livelihood strategies in Wolaita, southern Ethiopia. Agricultural Research and Reviews, 1(June), 153-161.

FABUSORO, E., OMOTAYO, A. M., APANTAKU, S. O., \& OKUNEYE, P. A. (2010). Forms and Determinants 
of Rural Livelihoods Diversification in Ogun State, Nigeria. Journal of Sustainable Agriculture, 34, 417-438. http://doi.org/10.1080/10440041003680296

FOSU-MENSAH, B. Y., VLEK, P. L. G. \& MACCARTHY, D. S. (2012). Farmers' perception and adaptation to climate change: a case study of Sekyedumase district in Ghana. Environmental Development Sustainable, 14, 495-505. http://doi.org/10.1007/s10668-012-9339-7

GREENE, W. H. (2002). Econometric analysis Seventh Edition.

JAGWE, J., MACHETHE, C. \& OUMA, E. (2010). Transaction costs and smallholder farmers' participation in banana markets in the Great Lakes Region of Burundi, Rwanda and the Democratic Republic of Congo. African Journal of Agricultural and Resources Economics, 6(1), 302-3017.

JANVRY, A. D. E. \& SADOULET, E. (2001). Income Strategies among rural households in Mexico : The role of Off-farm Activities. World Development, 29 (3), 467-480. KASSIE, G. W., KIM, S. \& FELLIZARJR, F. P. (2017). Determinant factors of livelihood diversification: Evidence from Ethiopia. Cogent Social Sciences, 26, 116. http://doi.org/10.1080/23311886.2017.1369490

LAY, J., MAHMOUD, T. O. \& M'MUKARIA, G. M. (2008). Few opportunities, much desperation: The dichotomy of non-agricultural activities and inequality in Western Kenya. World Development, 36(12), 2713-2732. http://doi.org/10.1016/j.worlddev.2007.12.003

LOISON, A. \& BIGNEBAT, C. (2017). Patterns and Determinants of Household Income Diversification in Rural Senegal and Kenya. Journal of Poverty Alleviation and International Development, 8, 93-126.

MAERTENS, M., MINTEN, B. \& SWINNEN, J. (2012). Modern food supply chains and development: Evidence from horticulture export sectors in Sub-Saharan Africa. Development Policy Review, 30(4), 473-497. DOI: https://onlinelibrary.wiley.com/doi/abs/10.1111/j.14677679.2012.00585.x

MARANDURE, T., MAPIYE, C., MAKOMBE, G., STRYDOM, P., MUCHENJE, V. \& DZAMA, K. (2016). Determinants and opportunities for commercial marketing of beef cattle raised on communally owned natural pastures in South Africa. African Journal of Range \&Forage Science, 33(3), 199-209. http://doi.org/10.2989/10220119.2016.1235617

MENTAMO, M. \& REGASSA, N. (2016). Livelihood diversification under severe food insecurity scenario among smallholder farmers in Kadida Gamela District, Southern Ethiopia. Kontakt, 8, 258-264.

MORRIS, W., HENLEY, A. \& DOWELL, D. (2017). Farm diversification, entrepreneurship, and technology adoption: Analysis of upland farmers in Wales. Journal of Rural Studies, 53, 132-143. http://doi.org/10.1016/j.jrurstud.2017.05.014

OMITI, J. M. \& MCCULLOUGH, E. (2009). Factors influencing the intensity of market participation by smallholder farmers : A case study of rural and peri-urban areas of Kenya. African Journal of Agricultural Research, $3,57-82$.

RANDELA, R., ALEMU, Z. G. \& GROENEWALD, J. A. (2008). Factors enhancing market participation by small- scale cotton farmers. Agrekon, 47(4), 451-469. https://doi.org/10.1080/03031853.2008.9523810

RIOS, R. A., MASTERS, A. W. \& SHIVELY, E. G. (2008). Linkages between Market Participation and Productivity: Results from a Multi-Country Farm Household Sample. Orlando, Florida.

SEBATTA, C., MUGISHA, J., KATUNGI, E., KASHAARU, A. \& KYOMUGISHA, H. (2014). Smallholder farmers' decision and level of participation in the potato market in Uganda. Modern Economy, 5, 895906. DOI: $10.4236 /$ me.2014.58082

SENG, K. (2016). The effects of market participation on farm households' food security in Cambodia: an endogenous switching approach (No. 69669). Munich Personal RePEc Archive. Waseda University, Japon.

SULTANA, N., HOSSAIN, E. \& ISLAM, K. (2015). Income diversification and household well-being: A Case study in rural areas of Bangladesh. International Journal of Business and Economics Research, 3, 172-179. http://doi.org/10.11648/j.ijber.20150403.20

TAREKEGN, K., HAJI, J. \& TEGEGNE, B. (2017). Determinants of honey producer market outlet choice in Chena District, southern Ethiopia: a multivariate probit regression analysis. Agricultural and Food Economics, 5, 1-14. http://doi.org/10.1186/s40100-017-0090-0

TEKLEWOLD, H., KASSIE, M. \& SHIFERAW, B. (2013). Adoption of Multiple Sustainable Agricultural Practices in Rural Ethiopia. Journal of Agricultural Economics, 64(3), 597-623. http://doi.org/10.1111/14779552.12011

THERIAULT, V., SERRA, R. \& STERNS, J. A. (2013). Prices, institutions, and determinants of supply in the Malian cotton sector. Agricultural Economics, 44, 161174. http://doi.org/10.1111/agec.12001

TRAORE, B. B., WIJK, M. T. V. A. N., DESCHEEMAEKER, K., CORBEELS, M., RUFINO, M. C. \& GILLER, K. E. (2015). Mali : Learning from farmer perceptions and on-farm trials. Expl Agriculture, 51, 615634. http://doi.org/10.1017/S0014479714000507

TUYEN, T. Q. (2015). Socio-Economic Determinants of Household Income among Ethnic Minorities in the NorthWest Mountains, Vietnam. CroEconSur, 17(1), 139-159. http://doi.org/10.15179/ces.17.1.5

VAN SCHALKWYK, H. D., GROENEWALD, J. A., FRASER, G. C., OBI, A. \& VAN TILBURG, A. (Ed.) (2012). Unlocking markets to smallholders. Wageningen Academic Publishers, 10, 1-12.

WINTERS, P., DAVIS, B., CARLETTO, G., COVARRUBIAS, K., QUINONES, E. J., ZEZZA, A. STAMOULIS, K. (2009). Assets, activities and rural income generation: Evidence from a multicountry analysis. World Development, 37(9), 1435-1452. http://doi.org/10.1016/j.worlddev.2009.01.010

WOOLDRIDGE, J. M. (2002). Econometric Analysis of Cross Section and Panel Data.

WORLD BANK (2008). Agriculture Development: World development report 2008, Washington, DC. 